\title{
FUNKCJA WYNIKAJĄCA Z FORMY - ADAPTACJA ARCHITEKTURY POWOJENNEGO MODERNIZMU DO NOWYCH PROGRAMÓW FUNKCJONALNYCH
}

\section{CIARKOWSKI Błażej ${ }^{1}$}

${ }^{1}$ dr inż. Błażej Ciarkowski, Instytut Historii Sztuki, Uniwersytet Łódzki

https://orcid.org/0000-0001-5661-3429

ABSTRAKT: Celem niniejszego artykułu jest analiza możliwości adaptacji obiektów architektury modernistycznej wzniesionych w Polsce po II wojnie światowej. Specyfika formy, która została zaprojektowana w duchu funkcjonalizmu, a więc dostosowana do określonego programu funkcjonalnego, znacznie utrudnia zmianę przeznaczenia obiektów. Podobnie rozwiązania materiałowe i konstrukcyjne, które (niekiedy ze względu na eksperymentalny, nowatorski charakter) źle znoszą próbę czasu.

Rozważania nad wprowadzaniem nowych programów funkcjonalnych przy jednoczesnym zachowaniu autentyzmu obiektów zostały zilustrowane wybranymi przykładami realizacji, mającymi udowodnić tezę, iż efekt finalny procesu adaptacji zależny jest m.in. od właściwej interpretacji substancji historycznej i idei będącej jej genezą.

SŁOWA KLUCZE: Modernizm, powojenny modernizm, adaptacja

1 Artykuł został opracowany w ramach międzynarodowego projektu Innovative materials and techniques for conservation of 20th century concrete-based heritage (InnovaConcrete), program ramowy: Horyzont 2020, H2020-NMBP-2016-2017, Grant Agreement: 760858. 


\section{Dziedzictwo modernizmu i jego specyfika}

Rozważania nad teoretycznymi podstawami adaptacji architektury powojennego modernizmu do nowych programów funkcjonalnych rozpocząć należy od postawienia pytania: czy zabytki architektury modernistycznej wymagają innych strategii konserwacji niż relikty wcześniejszych epok? Problem ten był niejednokrotnie podejmowany przez teoretyków architektury, projektantów i konserwatoró ${ }^{2}$, a zagadnienia zawiązane $\mathrm{z}$ renowacją, adaptacją, czy wreszcie - „reprodukcją” zabytków, rozpatrywane były w świetle kluczowych dla modernizmu „idei dynamizmu i funkcjonalności”. Można przyjąć, że architektura modernistyczna wymaga „rozszerzonej” doktryny konserwatorskiej, a przedmiotem troski powinna być zarówno warstwa materialna zabytków, jak i idee, które ucieleśnia ${ }^{3}$. Wynika to wprost ze specyfiki ruchu nowoczesnego, który był nie tylko propozycją określonej estetyki, ale przede wszystkim - rewolucją opartą na nowych zasadach ideowych, etycznych i technicznych. Ścisłe połączenie nowoczesnej technologii z programem ideowym stanowiło o wyjątkowości modernizmu. W książce o znamiennym tytule „Mity i utopie architektury XX wieku”, Jakub Wujek przywołuje słowa twórców polskiej awangardy architektonicznej z lat 20. „Im ściślej praca będzie dopasowana do czasu, w którym żyjemy [...] tym bardziej [umysły - B.C.] będą nowoczesne, tym więcej będzie w nich modernizmu" - pisano ${ }^{4}$. Należy przy tym podkreślić, iż u swego zarania nie był to ruch o charakterze futurystycznym. „Modernizm to chwila bieżąca” - konkludował w 1926 roku Szymon Syrkus ${ }^{5}$. Celem modernistów było rozwiązanie aktualnych problemów „tu i teraz”. Niejednokrotnie wiązało się to z „tymczasowością” obranych rozwiązań i metod, które po rozwiązaniu danego problemu tracily rację bytu. Sanatorium dla chorych na gruźlicę Zonnestraal w Hilversum zostało zaprojektowane przez holenderskiego architekta Jana Duikera w 1926 roku. Projektant przewidywał, że gruźlica, jako jedna z chorób cywilizacyjnych, zostanie niemal doszczętnie wypleniona w ciągu 30-40 lat. Wobec tego zastosował rozwiązania stosunkowo nietrwałe, przeczące witruwiańskiej zasadzie „firmitas”. Dopiero pełne zrozumienie genezy zastosowania przez Duikera określonych rozwiązań materiałowych i technologicznych pozwoliło stworzyć kompleksowy program renowacji i adaptacji, którego autorem był Wessel de Jonge ${ }^{6}$.

„Architekci modernistyczni wierzyli, że zmiany są nieuniknione i że architektura powinna dostosowywać się do zmieniających się okoliczności, ale zużywanie architektury nie stanowiło

\footnotetext{
2 Por. Piątek G., Trybuś Jarosław, Lukier i mięso, Wyd. Stowarzyszenie 40000 Malarzy, Warszawa 2012, s. 131134.

3 Heynen H., Problem przemijalności w architekturze nowoczesnej, „Autoportret. Pismo o dobrej przestrzeni” 2016, nr 2 (53), s. 10.

Wujek J., Mity i utopie architektury XX wieku, Arkady, Warszawa 1986, s. 211.

Syrkus Sz., Preliminarz Architektury, „Praesens”1926, nr 1, s. 6.

6 De Jonge W., Three modern preservation cases. The restoration of Rietveld's Biennale Pavilion (1953-54) in Venice, Italy, compared to Sanatorium "Zonnestraal" (Jan Duiker, 1926-28) and the Van Nelle Factories (Brinkman \& Van der Vlugt, 1926-31), Text previously publisher as a chapter in the RAIA Sisalation Publication, Sydney, 2004, [za:] www.wesseldejonge.nl (dostęp: 14.02.2013).
} 
celu" - pisała Hilde Heynen ${ }^{7}$. Sam fakt, iż dany budynek był projektowany i budowany z myślą o konkretnym okresie użytkowania (jak miało to miejsce w przypadku Zonnestraal) nie oznacza jednak, że jego utrzymanie i konserwacja są niewłaściwe. Heynen podkreśla, że strategia zachowania dziedzictwa ruchu nowoczesnego „zakłada balansowanie pomiędzy wierną reprodukcją oryginalnego projektu oraz dynamiczną renowacją, która akceptuje nowe funkcje i tym samym odzwierciedla pierwotne założenia ideowe budynków"s.

Modernistyczni twórcy wprowadzili do języka architektury pojęcia, które wcześniej nie były jego stałymi elementami - wśród najważniejszych wymienić należy „prawdę”, rozumianą jako „autentyczność" i „szczerośćc". Filozoficzne i ideowe podstawy ruchu nowoczesnego w wielu przypadkach wpływają na przyjęte strategie konserwacji i adaptacji modernistycznych dzieł architektury. Ich nieznajomość lub niezrozumienie prowadzi niejednokrotnie do stosowania rozwiązań wątpliwych, które zaburzają właściwą recepcję obiektu. Niechlubny przykład tego typu rozwiązań stanowić może pawilon Instytutu Fizyki Uniwersytetu Łódzkiego, który w zamyśle twórcy, Bolesława Kardaszewskiego, miał stanowić manifest maszynowej estetyki późnego modernizmu wyrażonej poprzez surowe, żelbetowe, prefabrykowane elementy ${ }^{10}$. Wykonana w 2005 roku termomodernizacja obiektu bezpowrotnie zniekształciła jego odbiór. Podobnie ocenić można znacznie subtelniej przeprowadzoną modernizację konstrukcji wieży do skoków do wody na kąpielisku Kursaal we włoskiej Ostii. Żelbetowy krąg zaprojektowany w 1950 roku przez Pier Luigi Nerviego zastąpiony został identyczną konstrukcją z drewna klejonego. Działanie to krytykował Fulvio Irace z Politechniki Mediolańskiej podkreślając, że w konstrukcji kształt był równie ważny jak materiał, bowiem twórcy chodziło o zaprezentowanie niemal nieskończonych możliwości kształtowania struktur żelbetowych ${ }^{11}$.

\section{Zabytek a dzieło sztuki}

Postrzeganie zabytków architektury jako dzieła sztuki o skończonej, zamkniętej (niejako spetryfikowanej przez czas) formie ogranicza możliwości jego adaptacji. Już w drugiej połowie XIX wieku Eugène Viollet-Le-Duc uważał, że zabytki, aby istnieć, powinny „żyć” być użytkowane. W tym upatrywał ich szans na przetrwanie kolejnych wieków, bowiem zabytek pozbawiony funkcji stawał się zabytkiem martwym, a często - także niepotrzebnym społeczeństwu. Alois Riegl, który u schyłku XIX stulecia tworzył zręby teorii wartości zabytków niemal całkowicie pominął problem ich funkcji. Dopiero w latach 60. XX wieku Walter Frodl w swojej koncepcji wartościowania zabytków wprowadził, pośród innych wartości, także tę

Heynen H., op. cit., s. 10.

8 Ibidem.

9 Por. Ciarkowski B., Kryterium autentyczności a wartościowanie zabytków architektury modernistycznej, [w:] Wartościowanie zabytków architektury, red. B. Szmygin, PKN Icomos, Warszawa 2013, s. 71-76.

10 Kardaszewski B., Dzielnica Wyższych Uczelni: Instytut Fizyki Uniwersytetu Łódzkiego, „Architektura” 1986, nr 429, s. 73-80.

11 Irace F., Overview on concrete Cultural Heritage in the Mediterranean area, wykład podczas InnovaConcrete Rome Workshop. The Concrete Architecture in the Mediterranean Areas and the work of Pier Luigi Nervi, Rzym, 22.02.2019. 
dotyczącą jego użytkowania i funkcjonalności. Opierając się na „Carta del restauro" konstatował, iż nowa funkcja nie powinna zbytnio odbiegać od oryginalnej, by nie wymuszać daleko idących przekształceń w historycznej substancji zabytku ${ }^{12}$.

Problem przystosowania zabytków do nowych funkcji, lub też zachowania funkcji oryginalnej, staje się jednym $\mathrm{z}$ najważniejszych wyzwań przed jakimi stają współczesne służby konserwatorskie, architekci oraz teoretycy. Nieużytkowany obiekt skazany jest na powolne unicestwienie, ale jednocześnie niewłaściwie dobrany program nierzadko oznacza utratę pierwiastków stanowiących o wyjątkowości danego budynku czy zespołu. Adaptacja budynku bądź zespołu budynków na potrzeby nowych funkcji często związana jest z szeregiem przekształceń. Ich granicę powinna wyznaczać integralność zabytku, a w przypadku architektury modernistycznej - także jedność formy i stojącej za nią idei.

Kolejnym wyzwaniem, przed którym stają konserwatorzy oraz architekci jest wartość symboliczna architektury modernistycznej. Mieczysław Wallis uważał, że „dzieła architektury współczesnej (...) nie mają na ogół treści semantycznych lub symbolicznych" ${ }^{\prime 3}$. Z perspektywy lat trudno zgodzić się z tym twierdzeniem. Moderniści odrzucili istniejącą symbolikę zastępując ją zupełnie nowym językiem architektury. Wyeksponowany w elewacjach marsylskiej Unite d'Habitation beton brut miał dla Corbusiera wymiar znaku, któremu przypisywał niemalże ludzkie przymioty takie jak „lojalność [...] godność i uczciwość"14. Podobną rolę odgrywało szerokie stosowanie szkła, eksponowanie konstrukcji budynku („szczerość konstrukcji”) czy nawet stosowanie określonej kolorystyki. Uczytelniony szkielet konstrukcyjny i szklane ściany w Casa del Fascio w Como (arch. Giuseppe Terragni) symbolizowały transparentności i uczciwości. Powtarzalne, zunifikowane formy budynków mieszkalnych w Hawrze (arch. Auguste Perret) wskazywały na egalitarny charakter architektury i zamieszkującej je społeczności. Jednocześnie część badaczy wyraża wątpliwości związane z restaurowaniem architektury modernistycznej. Jak przekonuje Alan Colquhoun - przywracając oryginalny wygląd budynku tworzymy obraz przeszłości, podczas gdy w zamyśle twórców miał on być obrazem najnowszych osiągnięć technologii ${ }^{15}$. Rozważania nad tym swoistym paradoksem podjęła także Hannah Lewi, poszukująca rieglowskiej „wartości pamiątkowej” w dziełach ruchu nowoczesnego. Przestrzegała przed dążeniami do „retuszowania” modernistycznych artefaktów poprzez usuwanie patyny czasu, która nieuchronnie prowadzi do umieszczenia modernizmu $\mathrm{w}$ jednym szeregu $\mathrm{z}$ innymi stylami historycznymi ${ }^{16}$.

12 Frodl W., Pojęcia i kryteria wartościowania zabytków. Ich oddziaływania na praktykę konserwatorską, „Biblioteka Muzealnictwa i Ochrony Zabytków” Seria B - Tom XIII, Warszawa 1966, s. 25-26.

13 Wallis M., Semantyczne i symboliczne pierwiastki architektury, [w:] M. Wallis, Wybór pism estetycznych, TAiWPN Universitas, Kraków 2004, s. 269.

14 Jencks Ch., Le Corbusier - tragizm wspólczesnej architektury, Warszawa 1982, s. 156.

15 Colquhoun A., Modernity and the Classical Tradition: Architectural Essays 1980-1987, MIT Press, Cambridge Massachusetts 1989, s. 240.

16 Lewi H., Paradoxes in the Conservation of the Modern Movement, [w:] Back from Utopia. The Challenge of the Modern Movement, red. Henket Hubert-Jan, Heynen Hilde, 010 Publishers, Rotterdam 2002, s. 355-357. 


\section{Forma a funkcja}

Jan Tajchman stwierdził, że adaptacja obiektów zabytkowych do nowych programów funkcjonalnych powinna być prowadzona $\mathrm{w}$ taki sposób, aby dążyć do „wydobycia i wyeksponowania wszystkich wartościowych elementów z jednoczesnym zachowaniem dawnego układu przestrzennego, w który mogła być jedynie wpisana, a nie wcięta nowa funkcja" ${ }^{\prime 17}$. Przystosowanie budynku do potrzeb odmiennych od pierwotnego przeznaczenia wymaga szeregu modyfikacji, których zakres jest przeważnie tym większy, im bardziej nowa funkcja różni się od starej.

Wlatach 20.XX wieku holenderskiarchitekt AdolfBehne wyróżniłdwa podstawowe nurty obecne $\mathrm{w}$ architekturze nowoczesnej: racjonalizm i funkcjonalizm ${ }^{18}$. Do pierwszego $\mathrm{z}$ nich zaliczył te realizacje, które, jego zdaniem, posiadały stosunkowo elastyczną strukturę zdolną akomodować różne funkcje. Ich przeciwieństwem były obiekty zaliczone do drugiej grupy, których forma, zgodnie z koncepcją Louisa Sullivana, wynikała wprost z przyjętego programu funkcjonalnego. Dzięki temu wydawały się być niemal idealnie dopasowane do konkretnego przeznaczenia, aczkolwiek ich zdolności adaptacyjne były stosunkowo ograniczone. Wprowadzony przez Behne podział nie tylko stanowi jedną z koncepcji usystematyzowania dorobku ruchu nowoczesnego w architekturze, ale stał się też punktem wyjścia dla współcześnie działających konserwatorów zabytków określających strategię prac przy obiektach modernistycznych ${ }^{19}$.

Wessel de Jonge, opierając się na przemyśleniach A. Behne, odwrócił maksymę Sullivana. $\mathrm{O}$ ile bowiem $\mathrm{w}$ procesie projektowania nowych budynków forma architektury może być wypadkową jego przeznaczenia, o tyle w przypadku adaptacji obiektów zabytkowych konieczne jest dostosowanie programu funkcjonalnego do zastanych warunków. „Function follows form”stwierdził de Jonge charakteryzując dwie ze swoich najważniejszych realizacji. Racjonalistyczna fabryka Van Nelle w Rotterdamie stała się przestrzenią wykorzystywaną m.in. przez tzw. przemysł kreatywny. Pozwoliła na to elastyczna struktura wnętrz, w które możliwe było zarówno zaaranżowanie audytoriów, warsztatów czy pracowni, jak i przestrzeni biurowych. Funkcjonalistyczne sanatorium Zonnestraal „wymusiło" z kolei wprowadzenie funkcji zbliżonej do oryginalnej - dawne pomieszczenia dla chorych na gruźlicę stały się ośrodkiem terapeutycznym.

Adaptacja funkcjonalistycznej architektury do nowych programów związana jest z licznymi ograniczeniami. Gdy członkowie Międzynarodowego Komitetu ds. Willi Tugendhatów (THICOM) opracowywali kompleksowy program renowacji dzieła Miesa van der Rohe w Brnie,

17 Brodzka J., Ciarkowski B., Konserwacja i kreacja architektury. Jan Tajchman i jego działalność, Wydawnictwo TAKO, Torun 2014, s. 33.

18 De Jonge W., The Technology of Change: The Van Nelle Factories in Transition, [w:] Back from Utopia. The Challenge of the Modern Movement, red. Henket Hubert-Jan, Heynen Hilde, 010 Publishers, Rotterdam 2002, s. 46-47.

19 De Jonge W., Three modern preservation cases. The restoration of Rietveld's Biennale Pavilion (1953-54) in Venice, Italy, compared to Sanatorium "Zonnestraal" (Jan Duiker, 1926-28) and the Van Nelle Factories (Brinkman \& Van der Vlugt, 1926-31), Text previously publisher as a chapter in the RAIA Sisalation Publication, Sydney, 2004, [za:] www.wesseldejonge.nl (dostęp: 14.02.2013). 
dążyli do wiernego odtworzenia rozwiązań materiałowych i funkcjonalnych z 1929 roku. Jednocześnie w związku z nową funkcją muzealną (zamiast mieszkalnej) musieli wprowadzić określone zmiany - w tym toalety i punkt obsługi zwiedzających, które umieszczono w podziemiu by nie naruszać integralności obiektu ${ }^{20}$.

Problem adaptacji budynków modernistycznych wydaje się szczególnie istotny w przypadku realizacji powstałych po II wojnie światowej. Rozwój technologii, upowszechnienie żelbetu oraz rosnąca popularność prefabrykacji w budownictwie sprawiły, że powojenny późny modernizm ${ }^{21}$ zyskał indywidualny charakter. Dążenia projektantów do optymalizacji rozwiązań osiągnęły niespotykany wcześniej poziom, który, nawiązując do terminologii wprowadzonej przez A. Behne, możemy określić jako „skrajny funkcjonalizm”. Mimo deklarowanej elastyczności i podatności na zmiany, w przeważającej większości przypadków to architektura miała kształtować zachowania użytkowników, a nie odwrotnie.

Wessel de Jonge zwraca uwagę, że w trakcie analizy wartości architektury nowoczesnej przeznaczonej do adaptacji jest ich właściwa interpretacja ${ }^{22}$. Przykładem działań popartych dogłębnymi analizami jest restauracja dawnego domu dziecka w Amsterdamie autorstwa Aldo van Eycka. Zaprojektowany $\mathrm{w}$ drugiej połowie lat 50 . XX wieku budynek stanowił kamień milowy w rozwoju tendencji strukturalistycznych $\mathrm{w}$ architekturze. W latach 90. przekształcono go w biurowiec, a za projekt adaptacji odpowiadali Aldo i Hannie van Eyck. Prowadzone w latach 2015-2017 prace pod kierunkiem de Jonge miały na celu powrót do pierwotnych założeń. W myśl przyjętej „purystycznej” strategii usunięto wszelkie nawarstwienia zakłócające odbiór oryginalnej koncepcji, w tym te wprowadzone przez samego van Eycka ${ }^{23}$. Jednocześnie dostosowano budynek do wymogów współczesnej przestrzeni biurowych (m.in. w zakresie oświetlenia) szukając kompromisu między czytelnością idei, a funkcjonalnością, która czyni dawny sierociniec „żyjącym dziedzictwem”24.

Niestety, podobne sytuacje należą do rzadkości. Wynika to zarówno z licznych trudności związanych $\mathrm{z}$ adaptacją dziedzictwa późnego modernizmu, jak i wciąż niedostatecznej świadomości jego wartości. Popularny argument o znikomej wartości architektonicznej i artystycznej poszczególnych obiektów wydaje się być usprawiedliwieniem, a nie przesłanką opartą na rzetelnych analizach i waloryzacji. Adaptacja wzniesionego w 1969 roku budynku

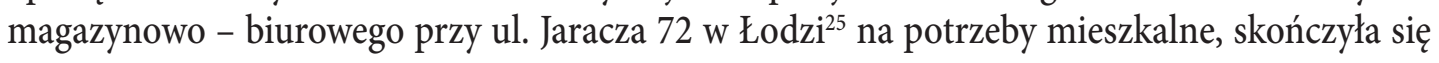

20 Tostoes A., Ochrona dziedzictwa modernizmu - renowacja trzech arcydzieł architektury XX wieku, [w:] Modernizm w Europie, modernizm w Gdyni. Architektura XX wieku, jej ochrona i konserwacja w Gdyni i w Europie, red. M. J. Sołtysik, R. Hirsch, Gdynia 2018, s. 136.

${ }^{21}$ Dotyczy to przede wszystkim późnego modernizmu, brutalizmu, strukturalizmu oraz tendencji metabolistycznych w architekturze.

22 Clarke N., Zijlstra H., De Jonge W., Education for Adaptive Reuse - The TU Delft Heritage and Architecture Experience, „Docomomo Journal” 2019, nr 3 (61), s. 70.

${ }^{23}$ de Jonge W., Myth and Metamorphosis: Aldo van Eyck's Orphanage (1960) in Amsterdam Restored, [w:] Metamorphosis. The Continuity of Change. 15IDC Conference proceedings, red. A. Tostoes, N. Koselj, Docomomo International - Docomomo Slovenia, Ljubljana 2018, s. 590.

24 Ibidem, s. 592.

25 Ciarkowski B., Bolesław Kardaszewski. Architektura i polityka, TAiWPN Univeristas, Kraków 2016, s. 59. 
całkowitą przebudową obiektu autorstwa Bolesława Kardaszewskiego, z którego pozostawiono jedynie żelbetowy szkielet konstrukcyjny. Podobny charakter miało przekształcenie dawnego budynku zakładów odzieżowych im. A. Próchnika w Łodzi na cele biurowe. Pierwotny obiekt posiadał nietypowy układ funkcjonalny wymuszony niewielką powierzchnią działki - w 8 kondygnacyjnej części wysokiej zlokalizowane były hale produkcyjne, a w piętrowym, rozłożystym pawilonie znajdowały się biura ${ }^{26}$. Zakres przeprowadzonej w latach 2007-2009 przebudowy zmienił zarówno układ bryły (likwidacja niskiej partii obiektu), wygląd elewacji (zastąpienie betonowych prefabrykatów oraz metalowych „żyletek” przez szkło zespolone), jak i układ wnętrz.

\section{Nowa funkcja a zakres interwencji}

Przykłady adaptacji architektury powojennego modernizmu w Polsce unaoczniają szerokie spektrum koncepcji i strategii przyjmowanych przez inwestorów i architektów. Jednocześnie, pomimo znacznej różnorodności typologii samych budynków czy charakteru nowej funkcji, zdają się potwierdzać hipotezę, że warunkiem koniecznym jest poprzedzająca działania projektowe wnikliwa analiza zasad rządzących oryginalną strukturą oraz związany z nią dobór nowego sposobu użytkowania.

W 2009 roku przeprowadzona została adaptacja dolnego pawilonu stacji Warszawa Powiśle na klubokawiarnię. Wzniesiony w 1963 roku według projektu Arseniusza Romanowicza i Piotra Szymaniaka pawilon o charakterystycznym żelbetowym łupinowym przekryciu w kształcie dysku pierwotnie mieścił kasy biletowe. Jedna $\mathrm{z}$ autorek projektu adaptacji, Małgorzata Kuciewicz z Grupy Projektowej Centrala, opisała szereg problemów, z jakimi musieli zmierzyć się architekci, którzy postanowili przekształcić niewielki obiekt na punkt gastronomiczny. Poszerzenie przestrzeni sali wiązało się z ograniczeniem wielkości zaplecza kuchennego. Ponadto możliwe było zrealizowanie zaledwie jednej toalety, co wynikało $\mathrm{z}$ istniejącego układu instalacji ${ }^{27}$. Daleko idące przekształcenia były niemożliwe do zrealizowania nie tylko $\mathrm{z}$ powodu przekonania projektantów o konieczności ograniczenia ingerencji w zastaną substancję do minimum, ale także ograniczonego budżetu. Z tego powodu nierozwiązany pozostał m.in. problem odprowadzenia wody deszczowej z niecki dachu ${ }^{28}$. Warto podkreślić, że wiele oryginalnych rozwiązań technicznych pawilonu stacji Warszawa-Powiśle musiało zostać wymienione pomimo staran architektów. Dotyczyło to np. stalowej ślusarki okiennej, która wykonana była metodą rzemieślniczą i okazała się praktycznie niemożliwych do odtworzenia ${ }^{29}$.

${ }^{26}$ Stefański K., Ciarkowski B., Modernizm w architekturze Łodzi XX wieku, Księży Młyn Dom Wydawniczy, Łódź 2018, s. 152-153.

27 Fudala T., Archeologia modernistyczna. Rozmowa z Małgorzata Kuciewicz (Grupa Projektowa Centrala), współautorka projektu renowacji i adaptacji dolnego pawilony stacji Warszawa-Powiśle, [w:] AR/PS Architektura Arseniusza Romanowicza i Piotra Szymaniaka, red. G. Piątek, Centrum Architektury, Warszawa 2012, s. 260261.

28 Ibidem, s. 261.

29 Ibidem, s. 261-263. 


\section{Błażej Ciarkowski}

Konserwatorskie podejście do budynku z pierwszej połowy lat 60. zaprezentowane przez projektantów z Centrali sprawiło, że Warszawa-Powiśle stała się niemal dokumentem prezentującym historię przekształceń obiektu. W porównaniu z nim pochodząca z 1952 roku dawna stacja tramwajów podmiejskich w Łodzi stanowi przykład odmiennej strategii. Zaprojektowany przez Witolda Wiśniewskiego i Romana Manna budynek został w 2014 roku zaadaptowany przez Michała Winiarskiego na siedzibę Łódzkiej Okręgowej Izby Architektów. Wykonano kompleksowy remont, zachowując jednocześnie oryginalny charakter bryły. Co ciekawe „Przystanek architektura”, bo taką nazwę otrzymał obiekt, nadal pełni swą pierwotną funkcję, a pod długim dachem łączącym przeszklone pawilony zajmowane przez łódzkich architektów, chronią się pasażerowie czekający na tramwaje.

Zachowanie oryginalnej funkcji obiektu wydaje się rozwiązaniem nader pożądanym, ale często niemożliwym do osiągnięcia. Warto w tym miejscu zwrócić uwagę, iż nierzadko wprowadzenie nowego programu funkcjonalnego pozornie podobnego do pierwotnego, może prowadzić do nieodwracalnych zmian w strukturze budynku i utraty jego istotnych wartości. Przykład takich działań stanowi wzniesione w 1975 roku wg projektu Stefana Łobacza łódzkie kino „Iwanowo”. Przekształcenie wolnostojącego obiektu w klub muzyczny sprawiło, że nowatorski system komunikacji wewnętrznej został trwale przekształcony ${ }^{30}$. Łobacz zaprojektował układ zbliżony do współczesnych multipleksów, z oddzieloną strefą wejścia i wyjścia. Wraz ze zmianą programu funkcjonalnego zostały one połączone. Podobny los spotkał zaprojektowany przez Wiktora Jackiewicza teatr w Łasku. Zrealizowany w 1968 roku niewielki obiekt stanowił przykład innowacyjnych rozwiązań $\mathrm{w}$ sferze relacji widza i aktora. W sali na planie sześcioboku zaprojektowano widownię wielokierunkową stałą, która dzięki ruchomym fotelom umożliwiała obserwację wydarzeń nie tylko na scenie głównej, ale i na scenach pobocznych ${ }^{31}$. Niestety, to nowatorskie rozwiązanie nie przetrwało próby czasu. Na tym tle chlubnym wyjątkiem wydaje się krakowskie kino „Kijów”, które utrzymało pierwotną funkcję. Budynek autorstwa Witolda Cęckiewicza nie tylko został zmodernizowany i dostosowany do oczekiwań współczesnych użytkowników przy zachowaniu charakteru bryły oraz najbardziej istotnych elementów wystroju wnętrz, ale ponadto tożsamość miejsca budowana jest w oparciu o jego historię.

\section{Nowa funkcja a autentyczność}

Jednym $\mathrm{z}$ kluczowych zagadnień $\mathrm{w}$ procesie adaptacji budynków jest równoczesne przystosowanie ich do nowych funkcji i zachowanie autentyzmu. Jak już zostało wspomniane, powodzenie całego procesu zależy w znacznej mierze od świadomości projektanta oraz doboru odpowiedniego programu.

W latach 2015-2016 architekci z pracowni Grupa 5 Architekci (Roman Dziedziejko, Michał Leszczyński, Krzysztof Mycielski, RafałZelent, RafałGrzelewski, Maciej Dudkiewicz) opracowali projekt adaptacji budynku dawnej drukarni dziełowej w Łodzi na potrzeby nowoczesnego domu studenckiego. Obiekt został zaprojektowany w pierwszej połowie lat 60. przez Jerzego

30 Obecnie budynek pozostaje nieużytkowany.

31 Szafer T. P., Nowa architektura polska. Diariusz lat 1966-1970, Wydawnictwo Arkady, Warszawa 1972, s. 115. 
Brandysiewicza. Ze względu na rozbudowany program oraz niewielką powierzchnię parceli konieczne było spiętrzenie bryły i zmiana układu produkcji na pionowy. Drukarnia została zamknięta w 2012 roku, a brak bieżących remontów przyczynił się do stopniowej degradacji tkanki architektonicznej. Budynek nie był objęty ochroną konserwatorską, ale projektanci z G5A postanowili wpisać nowy, ściśle określony program funkcjonalny w historyczną strukturę obiektu poprzemysłowego przy jednoczesnym zachowaniu jego unikatowych walorów. Mimo iż stan techniczny części elementów nie pozwalał na ich zachowanie i konieczna była rekonstrukcja, a także rozbudowa obiektu, zachowano spójność estetyczną. W założeniach projektowych podkreślono konieczność ekspozycji historycznych rozwiązań istotnych dla charakteru dawnej drukarni, takich jak: „otwarty plan parteru, unikalną konstrukcję nośną budynku, prefabrykowane elementy elewacji”" ${ }^{32}$.

Pozytywnarecepcjałódzkiej realizacji autorstwa G5A stanowidowód, iżnawet funkcjonalistyczne budynki wzniesione $\mathrm{w}$ duchu późnego modernizmu mogą stanowić nośnik nowych treści i funkcji nie tracąc przy tym autentyzmu. Jednocześnie, jak podkreślają twórcy adaptacji dawnej drukarni, każdy obiekt stanowi odrębne zagadnienie wymagające wypracowania właściwej strategii działań.

Niestety, wciąż łatwiej wymieniać realizacje i projekty budzące wątpliwości i zastrzeżenia, niż przykłady jednoznacznie pozytywne. Do takich zaliczyć można m.in. hospicjum realizowane we wzniesionej na przełomie lat 50. i 60. łódzkiej „szkole tysiąclecia” przy ul. Pojezierskiej autorstwa Tadeusza Herburta. Architekt zaprojektował strukturę składającą się z połączonych ze sobą pawilonów o zróżnicowanej formie dostosowanej do funkcji (część dydaktyczna, warsztatowa, administracyjna). Był ona bezpośrednio uwarunkowana nowatorskimi, jak na czas realizacji, założeniami programu nauczania ${ }^{33}$. Przekształcenie obiektu na potrzeby służby zdrowia nie tylko wymusza całkowitą zmianę układu funkcjonalnego, ale także szereg przekształceń bryły budynku - w tym ograniczenie ilości przeszkleń.

W tym świetle poważne obiekcje budzą plany adaptacji na cele muzealne Hotelu Cracovia, jednego z najwybitniejszych przykładów powojennego modernizmu w Polsce. Szereg możliwych konfliktów pomiędzy nową funkcją a formą, wynikających m.in. z konstrukcji obiektu (poprzeczne ściany nośne, typowa wysokość kondygnacji) sprawiają, że trudno uwierzyć w słowa hiszpańskiego architekta Fernando Menisa twierdzącego, że „aby budynek [Cracoviiprzyp. aut.] był elastyczny, potrzebne są niewielkie interwencje" ${ }^{\prime 34}$.

32 Klimczak D., Życie i przestrzeń. Grupa 5 Architekci, Grupa 5 Architekci, Warszawa 2018, s. 140.

33 Stefański K., Ciarkowski B., op. cit., s. 152-153.

34 Skolimowska A., Muzeum Architektury w hotelu Cracovia, „Architektura-murator” 2017, nr 7, s. 22-23. 


\section{Błażej Ciarkowski}

\section{Podsumowanie}

„To, co powoduje degradację [późnomodernistycznych budynków - przyp. aut.], to nie materiał, żelbet czy ich architektura. To otaczająca aura" - stwierdził Fulvio Irace podczas jednego z wykładów, opisując osiedle Vele di Scampia w Neapolu i wskazując jednocześnie na możliwość adaptacji brutalistycznego kompleksu mieszkaniowego na luksusowe apartamenty czy hotele $e^{35}$. Zrozumienie idei późnomodernistycznej architektury oraz jej genezy wydaje się być kluczowym warunkiem dla procesu adaptacji do nowych programów funkcjonalnych bez utraty kluczowych wartości.

Rafał Zelent z G5A podkreśla, że adaptacja do nowych funkcji to podstawa pracy przy zabytkach. Wspominając o hotelu Cracovia i biurowcu Zarządu Budowy PKP w Krakowie, stwierdził, że „nie powinny stać się sarkofagami, tylko zmienić się tak, jak zmieniają się czasy [...] ikony takie jak kościół św. Stanisława Kostki w Warszawie czy sala BHP w Stoczni gdańskiej powinny zostać zakonserwowanymi w czasie kapsułami, ale większość obiektów powinna się zmieniać" ${ }^{\prime 36}$. Co ciekawe, autor projektów obu wymienionych budynków, Witold Cęckiewicz, wyraził zainteresowanie planowanymi adaptacjami, licząc, że dożyje chwili „gdy te budynki będą spełniać nowe funkcje" ${ }^{37}$. Zmiana jest bowiem, jak stwierdził Alain Badiou, siłą napędową nowoczesności ${ }^{38}$.

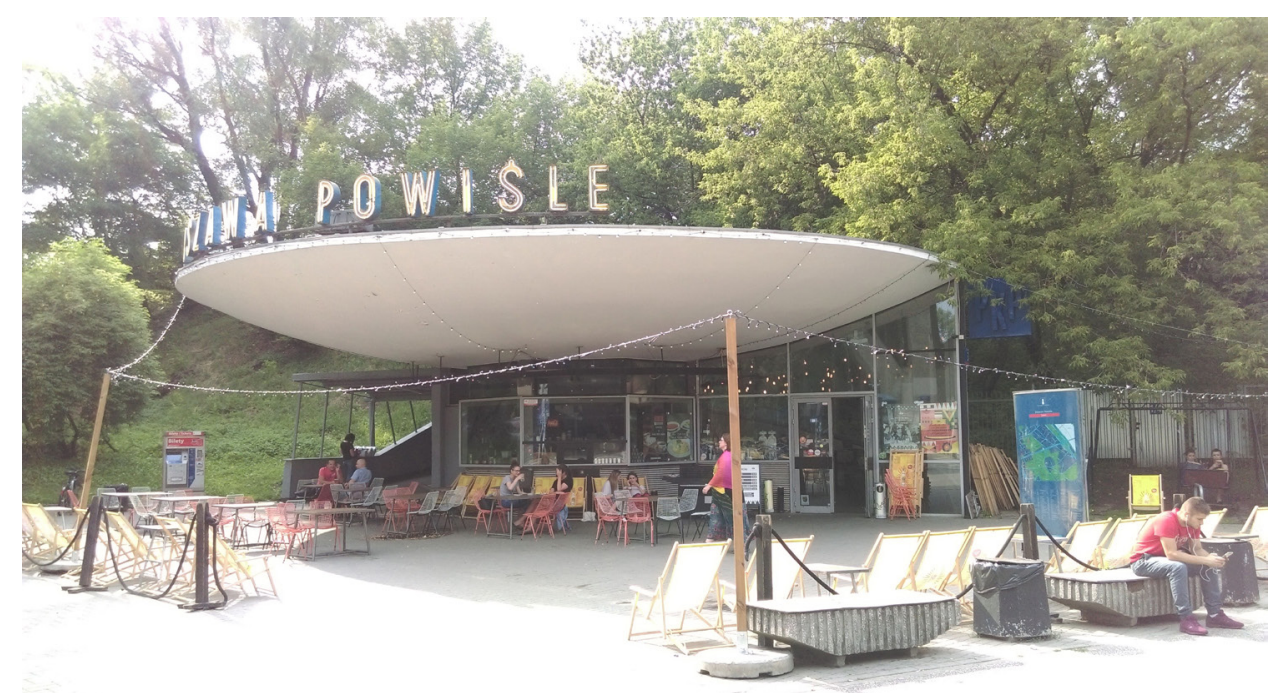

Ryc. 1 A. Romanowicz, P. Szymaniak, Dolny Pawilon Stacji Warszawa-Powiśle, Warszawa. Adapacja - Grupa Projektowa Centrala. (fot. B. Ciarkowski)

35 Irace Fulvio, op. cit.

36 Klimczak D., Życie i przestrzeń. Grupa 5 Architekci, Grupa 5 Architekci, Warszawa 2018, s. 131.

37 Ibidem.

38 Badiou A.,The Subject of Change: Lessons from the European Graduate School, New York-Dresden 2012. 


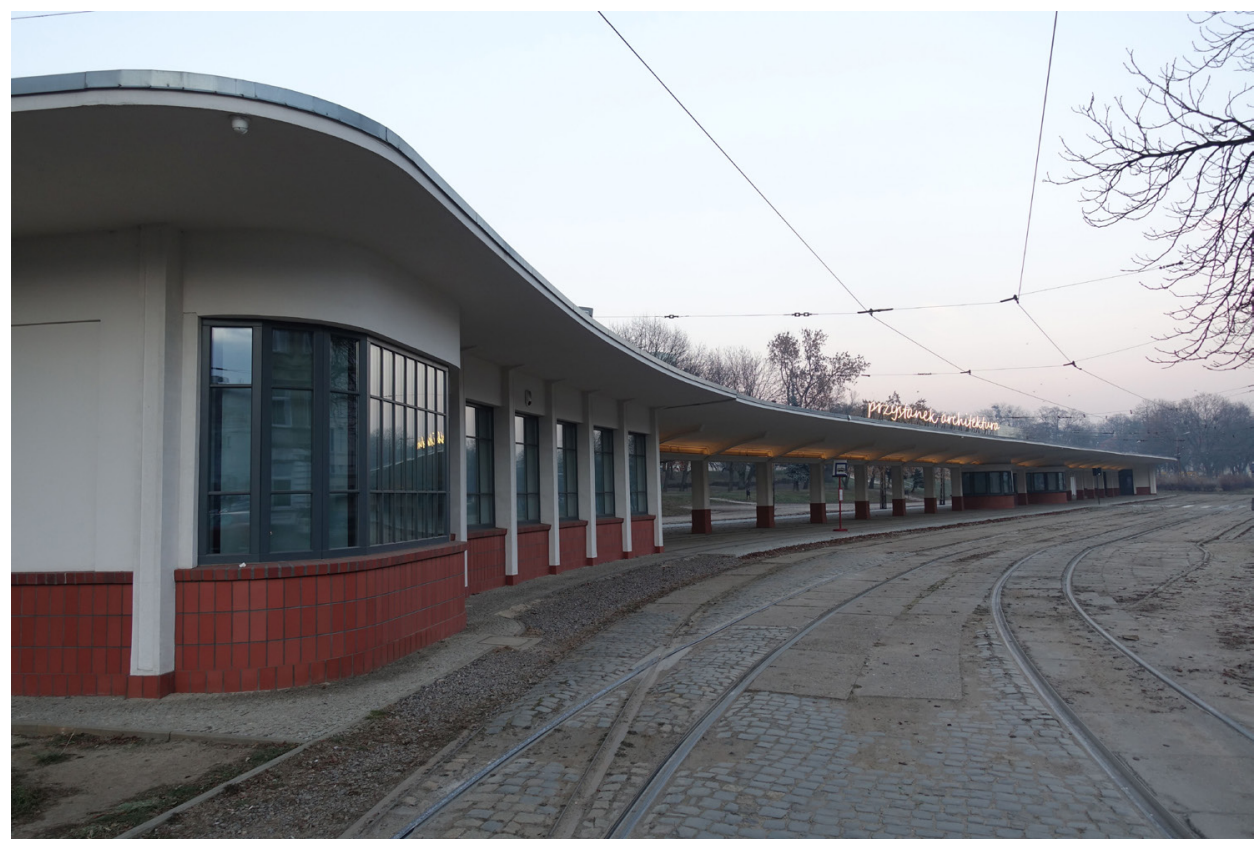

Ryc. 2 W. Wiśniewski, R. Mann, Przystanek tramwajów podmiejskich, Łódź. Adaptacja - Michał Winiarski. (fot. B. Ciarkowski)

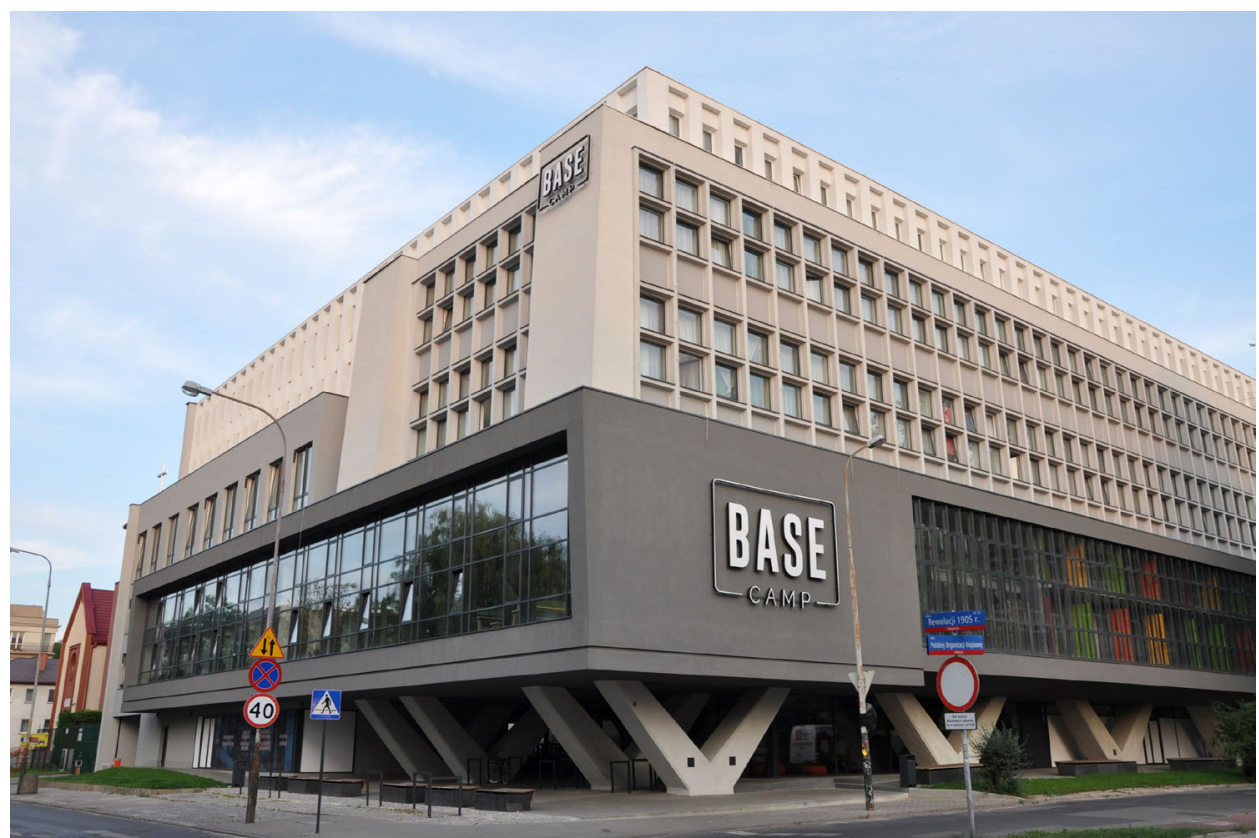

Ryc. 3 J. Brandysiewicz, Drukarnia dziełowa, Łódź. Adaptacja - Grupa 5 Architekci. (fot. B. Ciarkowski) 


\section{Błażej Ciarkowski}

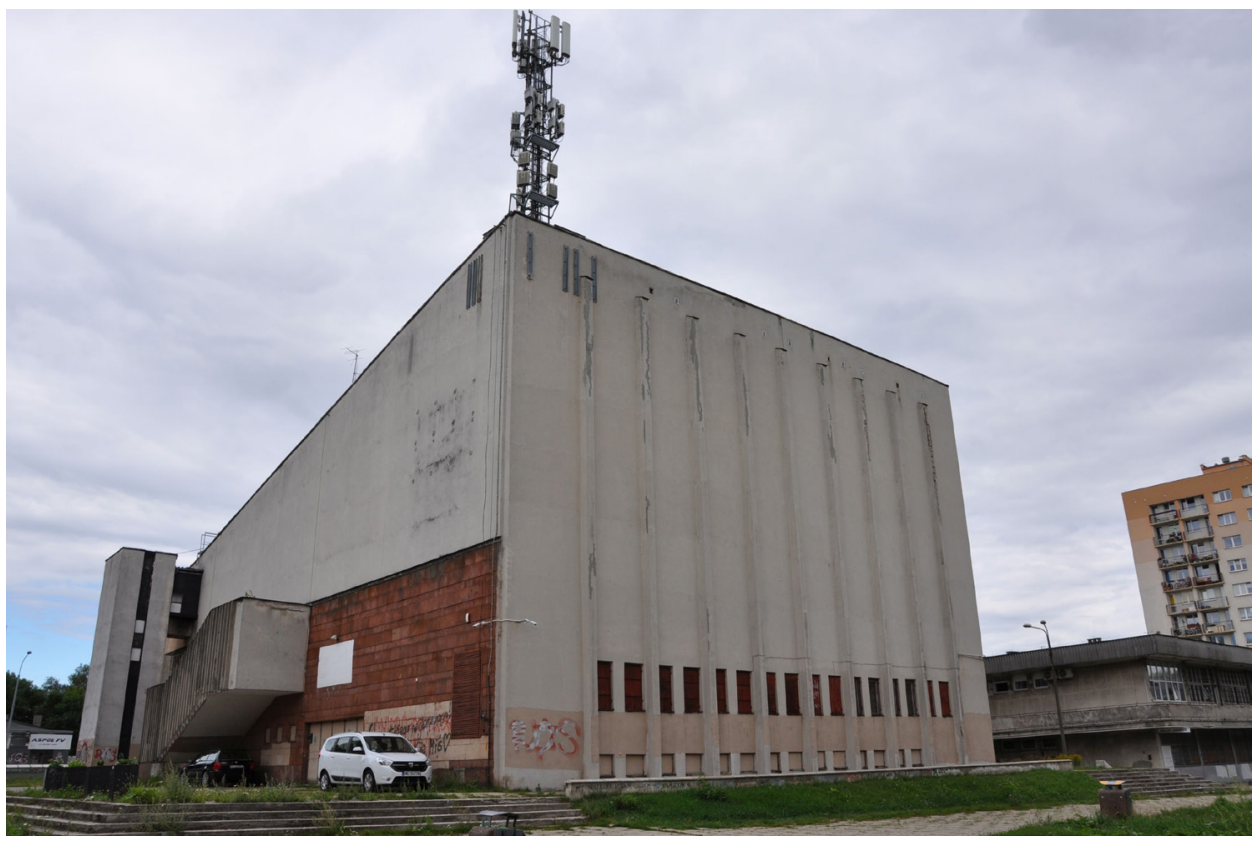

Ryc. 4 S. Łobacz, Kino „Iwanowo”, Łodź. (fot. B. Ciarkowski)

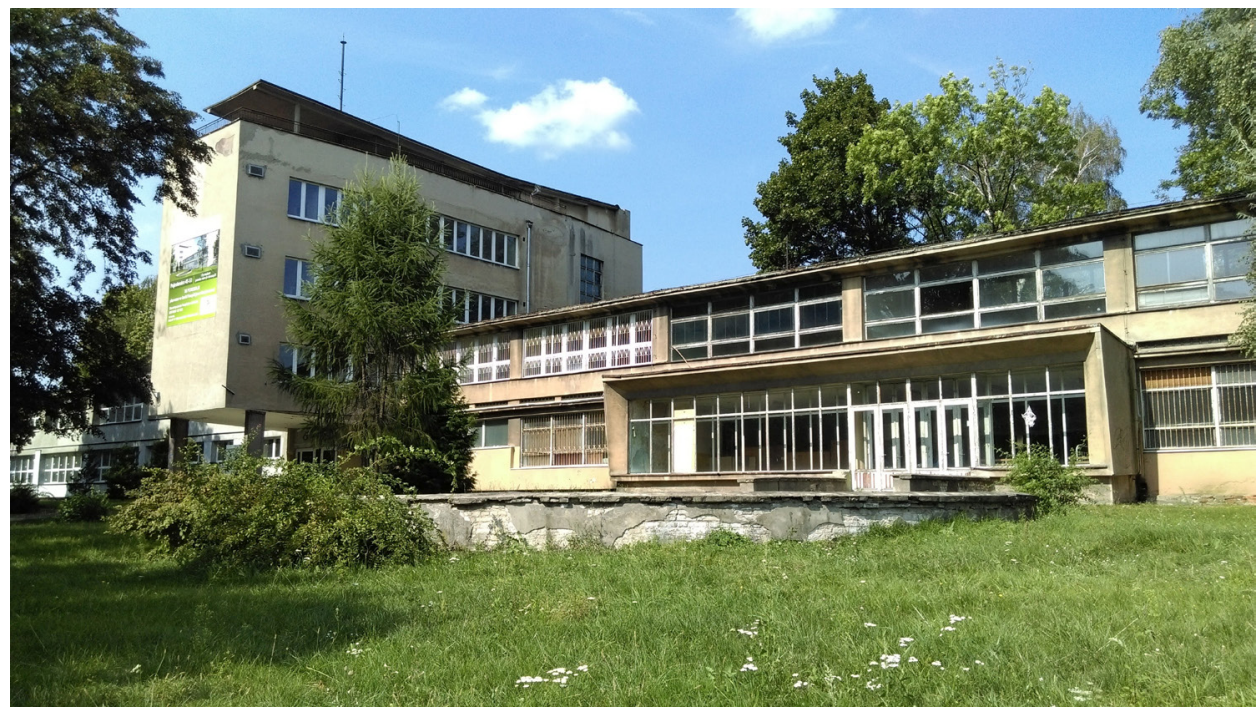

Ryc. 5 T. Herburt, Szkoła tysiąclecia przy ul. Pojezierskiej w Łodzi, Łódź. (fot. B. Ciarkowski) 


\section{Bibliografia}

Badiou A.,The Subject of Change: Lessons from the European Graduate School, New YorkDresden 2012.

Brodzka J., Ciarkowski B., Konserwacja i kreacja architektury. Jan Tajchman i jego działalność, Wydawnictwo TAKO, Torun 2014.

Ciarkowski B., Bolesław Kardaszewski. Architektura i polityka, TAiWPN Univeristas, Kraków 2016. Ciarkowski B., Kryterium autentyczności a wartościowanie zabytków architektury modernistycznej, [w:] Wartościowanie zabytków architektury, red. B. Szmygin, PKN Icomos, Warszawa 2013, s. 7176.

Clarke N., Zijlstra H., De Jonge W., Education for Adaptive Reuse - The TU Delft Heritage and Architecture Experience, „Docomomo Journal” 2019, nr 3 (61).

Colquhoun A., Modernity and the Classical Tradition: Architectural Essays 1980-1987, MIT Press, Cambridge Massachusetts 1989.

De Jonge W., Myth and Metamorphosis: Aldo van Eyck's Orphanage (1960) in Amsterdam Restored, [w:] Metamorphosis. The Continuity of Change. 15IDC Conference proceedings, red. A. Tostoes, N. Koselj, Docomomo Internationak - Docomomo Slovenia, Ljubljana 2018.

De Jonge W., The Technology of Change: The Van Nelle Factories in Transition, [w:] Back from Utopia. The Challenge of the Modern Movement, red. Henket Hubert-Jan, Heynen Hilde, 010 Publishers, Rotterdam 2002.

Frodl W., Pojęcia i kryteria wartościowania zabytków. Ich oddzialywania na praktykę konserwatorską, „Biblioteka Muzealnictwa i Ochrony Zabytków” Seria B - Tom XIII, Warszawa 1966.

Fudala T., Archeologia modernistyczna. Rozmowa z Małgorzata Kuciewicz (Grupa Projektowa Centrala), współautorka projektu renowacji i adaptacji dolnego pawilony stacji Warszawa-Powiśle, [w:] AR/PS Architektura Arseniusza Romanowicza i Piotra Szymaniaka, red. G. Piątek, Centrum Architektury, Warszawa 2012.

Heynen H., Problem przemijalności w architekturze nowoczesnej, „Autoportret” 2016, nr 2 (53).

Jencks Ch., Le Corbusier - tragizm wspótczesnej architektury, Warszawa 1982.

Kardaszewski B., Dzielnica Wyższych Uczelni:Instytut Fizyki Uniwersytetu Lódzkiego, „Architektura” 1986, nr 429, s. 73-80.

Klimczak D., Życie i przestrzeń. Grupa 5 Architekci, Grupa 5 Architekci, Warszawa 2018.

Lewi H., Paradoxes in the Conservation of the Modern Movement, [w:] Back from Utopia. The Challenge of the Modern Movement, red. Henket Hubert-Jan, Heynen Hilde, 010 Publishers, Rotterdam 2002.

Piątek G., Trybuś J., Lukier i mięso, wyd. Stowarzyszenie 40000 Malarzy, Warszawa 2012.

Skolimowska A., Muzeum Architektury w hotelu Cracovia, „Architektura-murator” 2017, nr 7.

Stefański K., Ciarkowski B., Modernizm w architekturze Łodzi XX wieku, Księży Młyn Dom Wydawniczy, Łódź 2018. 


\section{Błażej Ciarkowski}

Szafer T. P., Nowa architektura polska. Diariusz lat 1966-1970, Wydawnictwo Arkady, Warszawa 1972.

Tostoes A., Ochrona dziedzictwa modernizmu - renowacja trzech arcydzieł architektury XX wieku, [w:] Modernizm w Europie, modernizm w Gdyni. Architektura XX wieku, jej ochrona i konserwacja w Gdyni i w Europie, red. M. J. Sołtysik, R. Hirsch, Gdynia 2018.

Wallis M., Semantyczne i symboliczne pierwiastki architektury, [w:] M. Wallis, Wybór pism estetycznych, TAiWPN Universitas, Kraków 2004.

Wujek J., Mity i utopie architektury XX wieku, Arkady, Warszawa 1986. 